\title{
Causal effect of mergers and acquisitions on EU bank productivity
}

\author{
Abdussalam Aljadani ${ }^{1}$ and Hassen Toumi ${ }^{1,2^{*}}$
}

\author{
*Correspondence: \\ htoumi@taibahu.edu.sa; \\ toumihass@gmail.com \\ ${ }^{1}$ Department \\ of Management, College \\ of Business Administration \\ in Yanbu, Taibah University, \\ Madina, Kingdom of Saudi \\ Arabia \\ Full list of author information \\ is available at the end of the \\ article
}

\begin{abstract}
This paper examines the causal effect of mergers and acquisitions (M\&A) on bank productivity $(Q)$ in 23 European Union countries and the short- and long-term relationship among fixed assets ( $k 1$ ), liquid assets ( $k 2$ ), and labour (L) over the period 1990-2013 for a sample of 156 commercial banks, of which 60 entities have acquired at least one other entity. Granger causality tests on our results reveal unidirectional causality from liquid assets to fixed assets. However, the causality between $K 2$ and $L$ is unobservable, and the linkage between fixed assets and labour is bidirectional. The error correction term (ECT) is negative and statistically significant for all models, which denotes the presence of bidirectional relationship among all selected variables and long-term unidirectional causality from mergers and acquisitions to bank productivity. Our long-term dynamic panel estimates indicate that the strategic fit of mergers and acquisitions has the potential to create long-term productivity improvement.
\end{abstract}

Keywords: Mergers and acquisitions (M\&A), Productivity, Panel cointegration techniques

JEL Classification: L11, G15, G21, G24

\section{Introduction}

Over the last two decades, bank consolidation has been a frequent event in the financial sector in developing and developed countries, particularly in the European Union (Pozzolo 2009). Considering the subprime crisis, which negatively affected many advanced and emerging economies, particularly in the banking sector of the European Union, various solutions, such as mergers and acquisitions (M\&A), have appealed to these countries. M\&A represent external growth and approximately $80 \%$ of global foreign direct investment (FDI) flows (Klimek 2014). M\&A as a form of banking integration in the EU are one of many strategies of external growth; other strategies include trade agreements, conventions, and cooperation. Furthermore, it is recognized that productivity gains are primarily influenced by external growth, such as mergers and acquisitions (M\&A). However, none of these choices is considered as an ideal substitute in an emergency. Thus, many concerns have been raised, including the maximum level of cooperation. But the only consensus is that the larger the bank, the greater the need for cooperation. Nevertheless, the cooperation among commercial banks in the European Union is justified by efficiency gains in terms of profit or profitability. Yet, bank consolidation is

(c) The Author(s) 2019. This article is licensed under a Creative Commons Attribution 4.0 International License, which permits use, sharing adaptation, distribution and reproduction in any medium or format, as long as you give appropriate credit to the original author(s) and the source, provide a link to the Creative Commons licence, and indicate if changes were made. The images or other third party material in this article are included in the article's Creative Commons licence, unless indicated otherwise in a credit line to the material. If material is not included in the article's Creative Commons licence and your intended use is not permitted by statutory regulation or exceeds the permitted use, you will need to obtain permission directly from the copyright holder. To view a copy of this licence, visit http://creativeco mmons.org/licenses/by/4.0/. 
not compatible in terms of cost for the financial sector of these consolidated banks. This paper examines the causal effect of mergers and acquisitions (M\&A) on bank productivity in 23 European Union nations and the short- and long-term relationships between fixed assets, liquid assets, and labour for a sample of 156 commercial banks, of which 60 entities have undergone at least one acquisition or merger.

This survey is the first interpretive analysis of causality between mergers and acquisitions and bank productivity in the EU. In addition, the analysis examines the causal links between productivity, liquid assets, fixed assets, and labour. The empirical results reveal that the strategic fit of mergers and acquisitions has the potential to create long-term productivity improvement over the period of study.

This study has the following structure. Section 2 tests the short- and long-term effects of mergers and acquisitions on EU bank productivity. Section 3 describes the econometric methods used. Section 4 discusses the results of empirical testing. Finally, Sect. 5 presents the principal conclusions and offers recommendations.

\section{Literature review}

Among the desired effects of mergers and acquisitions (M\&A), we can confidently cite the research on economies of scale. Such economies involve reducing the average cost and surveying the market share of different entities. Empirical studies have focused on this topic, e.g. Cavallo and Rossi (2001) and Vannet (1994), who found economies of scale in the banking sector for the post-merger and acquisition (M\&A) period.

However, the research of Berger and Mester (1997), Allen and Rai (1996), and Altunbas and Molyneux (1996) includes a heterogeneous sample of banks from a variety of countries, such as the US and European Union members. Using panel data, Barth et al. (2004) also support the presence of economies of scale for acquired US banks and take into account the strong regulation in the banking sector.

In addition, it should be noted that several studies that have concentrated exclusively on the effects of mergers and acquisitions (M\&A) on bank productivity find controversial results compared to $M \& A$ studies that focus on the effects on or effectiveness, assets, or economies of scale of the newly merged entity for a variety of countries. Generally, most research has demonstrated that mergers and acquisitions (M\&A) generate productivity earnings. In fact, on the one hand, increases in bank size can occur during a merger and acquisition (M\&A), and on the other hand, the technological gains that are obtained can increase production factors. In addition, the new strategies that will be maintained by the new managers can result in better allocation of economic resources (efficiency $X$ ) and optimize the costs of banks in times of crisis. Finally, Nurboja and Košak (2017) discuss cost efficiency in EU and non-European countries. Their findings show that institutional adjustments outside EU countries should continue to abide by the same EU standards because EU banking systems tend to dominate in terms of measured cost efficiency. In emerging countries, empirical results indicate that merger and acquisition (M\&A) efficiency gains are generally weak except when implemented separately (Du and Sim 2016). Because of strong international competition, the challenge for transition countries is to pursue bank mergers and acquisitions (M\&A) and public sector privatization as the only solution. Therefore, the banking markets in emerging economies are heavily dominated by foreign capital (Bonin and Wachtel 2003). 
Several other studies examine efficiency gains in productivity in the EU after deregulation, particularly for the period 1980 to 1990, in anticipation of the level market (Brissimis et al. 2008). The empirical results reveal that EU banks realized average productivity gains after this deregulation, which occurs towards the end of the reform process for countries that become European Union members. Lichtenberg (1992) concluded that mergers and acquisitions (M\&A) could improve a company's effectiveness following a takeover. In fact, the process used is to argue for the improvement of the total productivity factor for the period of 14 years ( 7 years before and 7 years after) following a takeover in the bank productivity sector. The findings show that in the pre-merger period, the target framework has a total productivity factor considerably less than other firms. In addition, in the post-merger period, the gap decreases progressively over time. After 7 years of mergers and acquisitions (M\&A), the difference between the productivity of acquired entities and non-acquired entities is more important. This gain in productivity is partly due to new management strategies to reorganize the newly merged entities (e.g. a decrease in total occupation, the new organism of economic resources). Conyon et al. (2002) tested the impact of mergers and acquisitions by foreign banks on the bank productivity and wages of consolidating banks in the UK for the period 1989-1994. These authors conclude that these mergers generated a positive and significant effect on wages (i.e. a $3.4 \%$ increase) and increased productivity $13 \%$.

Haynes and Thompson (1999) reported the results of an empirical survey of the impact of mergers and acquisitions (M\&A) on productivity by using an augmented production function approach covering the period 1981 to 1993. These authors argue for a positive impact of mergers on productivity using financial intermediation activities. They note that the merged gains tend to increase gradually in the post-merger and acquisition period, during which significant cost minimization is observed.

Rezitis (2008) discusses the effect of acquisition activity on output and Greek bank productivity. The empirical results are comparatively contradictory with respect to the theoretical hypothesis. In fact, the author reveals that the effects of M\&A on Greek banks are relatively negative with respect to technical output and productivity. It is argued that the reduction in total productivity for the merged bank is due to two main factors: first, the technical short comings of the merged bank increase in the post-merger period; second, economies of scale are lost.

Oberhofer and Pfaffermayr (2013) confirmed evidence of a significant positive impact of acquisitions on employment at acquired businesses. This study examines the postacquisition growth of acquired businesses and employment and concludes that the acquired targets increase their employment growth rate after the transaction, which for the author is evidence of efficiency gains.

Vennet (1996) examines the effect of mergers and acquisitions (M\&A) on the performance of banking entities. His empirical research examined 422 national institutions and 70 multinationals spanning the period 1988 to 1993 . The study produced two fundamental results. First, domestic mergers between entities of identical size significantly increased the performance of the merged banks. Second, these mergers and acquisitions (M\&A) generated savings for national and multinational firms in the post-merger period. Furthermore, Shams and Gunasekarage (2019) examined the acquisition deals in Australia between public and private acquires firms. The empirical dealings show that 
public target improved performance in the long run when acquiring a significant holding stake in target firms.

Toumi et al. (2016) examine the dynamic effects of mergers and acquisitions (M\&A) on the performance of credit institutions in the EU for the period 2005 to 2013. Their empirical findings reveal that time has negative effects on efficiency gains. However, the composite effects of dummy variables of mergers and acquisitions (M\&A) over time generated a positive effect on bank performance. In the case of the EU, Ayadi et al. (2013) analyse the effects of mergers and acquisitions (M\&A) on productivity for the period 1996 to 2003. Their empirical results reveal a positive and significant effect of M\&A on consolidating banks. Amewu and Alagidede (2018) examine the relation between the stockholder dividends and the announcement of mergers and acquisitions of African banks. Their empirical findings demonstrate a positive relationship between bank productivity and merger and acquisition (M\&A) notification. In addition, Alarco (2018) examines the effect of merger and acquisition on production in Latin America for the period 1990-2014. Using an economic model with a production function, the study finds that mergers and acquisitions have the potential to create economic development in selected countries. In addition, bank mergers create added value with respect to the profitability of clients firms (Montgomery and Takahashi 2018). Montgomery and Takahashi's findings demonstrate that client entities of Japanese banks involved in megamergers do not enjoy welfare growth.

\subsection{Data}

Our survey involves annual data for the period 2005-2013, whereby bank productivity $(Q)$ is assessed by the sum of loans, headlines, and shares, labour $(L)$ is represented by the number of equivalent full-time employees, fixed assets $(K 1)$ represent the value of the (non-financial) fixed assets of the commercial banks, and liquid assets $(K 2)$ are represented by deposits and shares. The data are drawn from the balance sheets of commercial banks in the European Union (Bankscope database) (Appendix: Table 11). We perform econometric analyses based on a panel of 23 European countries: Portugal, the Czech Republic, Cyprus, Denmark, Ireland, Poland, Malta, Latvia, Belgium, Hungary, Germany, Finland, Estonia, Romania, Slovakia, Sweden, Spain, Greece, Bulgaria, France, the UK, Luxembourg, and Austria.

At this stage of the analysis, it is important to emphasize that our sample offers diverse reasons for adopting the type of analysis introduced in this study. Our study considers that the sample is sufficiently homogeneous to reveal the long-term effect of mergers and acquisitions on bank productivity (and is as homogeneous as those typically considered in other mergers and acquisitions studies). In contrast, the banking entities of the European Union should increase their likelihood of success to ensure a positive longterm productivity gain. Our sample is selected from the balance sheet of each bank using the intermediation (Table 1) approach of Sealey and Lindley (1977).

Table 1 summarizes the common sample descriptive statistics. We can detect that the $Q$ distribution is approximately symmetric, whereas the $K 1$ and $L$ distributions are highly skewed. The common means of $Q$ is (21.81032), $K 1$ is (16.67719), $K 2$ is (21.11658), and $L$ is (6.204740). In addition, the coefficient of variation (measured by the ratio: Std. Dev/Mean) for $Q$ is $(0.12005)$, for $K 1$ (0.1711), for $K 2(0.1168)$, and for $L(0.3407)$ in the 
Table 1 Descriptive statistics (data in logarithms)

\begin{tabular}{lllll}
\hline & $\mathbf{Q}$ & $\boldsymbol{K 1}$ & $\boldsymbol{K} \mathbf{2}$ & $\mathbf{L}$ \\
\hline Mean & 21.81032 & 16.67719 & 21.11658 & 6.204740 \\
Median & 21.59996 & 16.43291 & 20.98228 & 5.872118 \\
Maximum & 28.23852 & 24.18647 & 27.92952 & 11.92702 \\
Minimum & 8.588505 & 11.51293 & 14.07787 & 1.386294 \\
Std. dev. & 2.618492 & 2.853540 & 2.467150 & 2.114379 \\
Skewness & 0.235322 & 0.213156 & 0.095960 & 0.573195 \\
Kurtosis & 2.711278 & 2.275420 & 2.784411 & 2.833520 \\
Jarque-Bera & 17.94905 & 41.61038 & 4.901516 & 79.00583 \\
Probability & 0.000127 & 0.000000 & 0.086228 & 0.000000 \\
Sum & 30817.99 & 23564.87 & $29,816.62$ & 8767.298 \\
Sum sq. dev. & 9681.379 & $11,497.48$ & 8588.517 & 6312.487 \\
Observations & 1413 & 1413 & 1413 & 1413 \\
\hline
\end{tabular}

23 European Union nations. The normality distributions for these variables of different models of the 156 selected banks in the EU are rejected under the null hypothesis, as confirmed by the Jarque-Bera test.

\section{Conclusion and policy implications}

This paper examined the causal effect of mergers and acquisitions (M\&A) on bank productivity in 23 European Union nations $(Q)$ and the short- and long-term relationship between fixed assets $(k 1)$, liquid assets $(k 2)$, and labour $(L)$ over the period 1990-2013 for a sample of 156 commercial banks, of which 60 entities have acquired at least one other entity.

Our short-run Granger causality tests reveal bidirectional short-term causality between $\ln k 1, \ln k 2, \ln L$, and $\ln Q$, significant at $1 \%$ and $5 \%$, and similar causality between $\ln k 1$ and $\ln L$. Unidirectional short-term causality from liquid assets to fixed assets was significant at $1 \%$. Bidirectional short-term causality was found between $\ln k 1$ and $\ln L$. The short-term causality between $\ln k 2$ and $\ln L$ was unobservable. The error correction term (ECT) was negative and statistically significant for all selected models at $1 \%$, which indicates a bidirectional relationship among all selected variables and long-term unidirectional causality from mergers and acquisitions (M\&A) to bank productivity.

The FMOLS and DOLS long-run estimates support a long-term relationship between all selected variables. The total productivity of commercial banks in the European Union reveals an adjustment process for this productivity of $22 \%$.

In the short- and long-term models, capital and labour well explain the productivity of commercial banks in the European Union, while the gain effects of mergers and acquisitions are unobservable in the short term but apparent in the long term. As we move away from the time of merger, the banks make more productivity gains. This outcome is explained by the positive and significant coefficients associated with the dummy variables $\left(A_{0}, A_{3}\right.$, and $A$ for FMOLS) and ( $A_{3}$ and $A$ for DOLS).

As a policy implication of our results, EU countries should encourage their foreign investment banks to increase their merger and acquisition activity. Increasing the strategic fit of the merged banks will help them reduce their dependence and promote capital 
stock security. In addition, mergers and acquisitions have been a frequent response in European Union countries, and good management has contributed to the success of the integration process.

\section{Method}

The aims of our study are to determinate the short- and long-term effects of mergers and acquisitions on productivity and to analyse the causal links among production function, liquid assets, fixed assets, and capital-labour.

In the first step, we apply different unit root tests for the series to determine the order of integration. When selected series include a unit root, the second step is to investigate the long-term relationship between all considered variables using panel cointegration tests. Finally, we study the long-term relationship and causality linkages between all variables by the appropriate dynamic approach of panel cointegration using fully modified ordinary least squares (FMOLS) and dynamic ordinary least squares (DOLS).

In our sample, we adopt fictitious variable quads that explain the event of the merger and acquisition as follows: $A_{0}$ indicates that the merger has occurred; $A_{1}$ indicates that the merger occurred 1 year previously; $A_{2}$ indicates that the merger occur 2 years previously; $A_{3}$ indicates that the merger occur 3 years or more previously; $A$ indicates that the merger can occur at any time.

\subsection{Unit root test}

The existence of a unit root for selected variables is evaluated by several tests, such as the test of Levin et al. (2002), LLC, IPS, Fisher-ADF, and Fisher-PP. LLC, Fisher-ADF, and Fisher-PP assess the homogeneity of dynamic autoregressive distribution coefficients for all selected variables. However, IPS supposes a heterogeneous unit root in compliance with an alternative hypothesis.

The panel unit root tests assume all of the variables are not stationary at the level of intercept or trend (Table 2). However, all variables in the table of the panel unit root test with respect to the initial difference (Table 3 ) are stationary. Thus, we conclude that $Q$, $k 1, k 2$, and $L$ are integrated in order one I (1). Therefore, the FMOLS and DOLS techniques are appropriate for the entire series.

\subsection{Cointegration test}

The findings of the panel unit root test for productivity, liquid assets, fixed assets, and labour indicate that these four variables are integrated in the order I (1). One can observe that all selected variables are stationary with respect to first differences. Therefore, we can apply panel cointegration methods to examine the long-term relationships between $Q$, $K 1, k 2$, and $L$. The alternative of the long-term cointegration relationship is mentioned by Pedroni (1999, 2004) and Kao et al. (1999). The panel PP-statistic and panel ADF-statistic for each dimension and the group PP-statistic and group ADF-statistic are less than 1\% (Table 4). In addition, according to Kao, the ADF test is less than 1\% (Table 5). Thus, the cointegration procedure reveals long-term relationships between bank productivity, liquid assets, fixed assets, and labour for the European Union countries. 


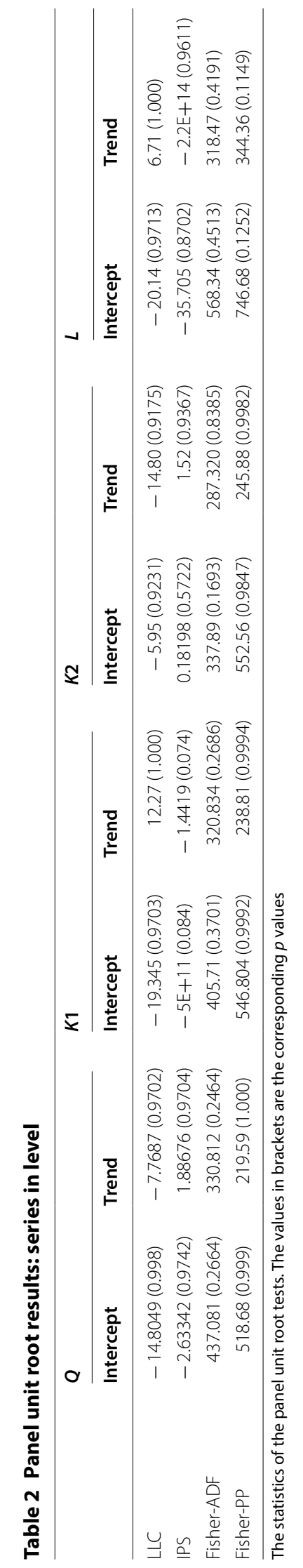




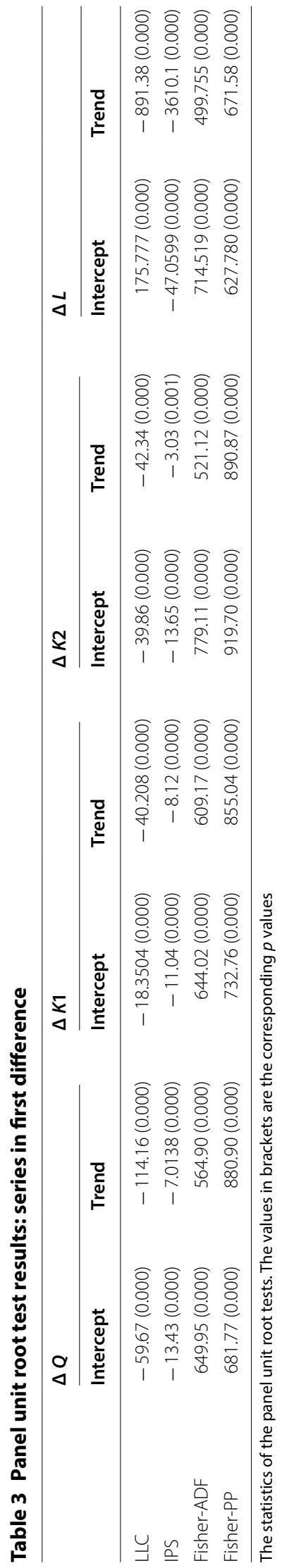


Table 4 Results of Pedroni panel cointegration test

\begin{tabular}{lcccccccc}
\hline & \multicolumn{3}{c}{ Within dimension } & \multicolumn{3}{c}{} & & \multicolumn{2}{c}{ Between dimension } \\
\cline { 2 - 5 } \cline { 7 - 8 } & Statistic & Prob. & Statistic & Prob. & & Statistic & Prob. \\
\hline Panel $v$-statistic & -5.9432 & 1.000 & -5.2869 & 1.000 & Group rho-Statistic & 13.1839 & 1.000 \\
Panel $\rho$-statistic & 6.4660 & 1.000 & 7.2590 & 1.000 & Group PP-Statistic & -18.3821 & $0.000^{* * *}$ \\
Panel PP-statistic & -12.1488 & $0.000^{* * *}$ & -10.301 & $0.000^{* * *}$ & Group ADF-Statistic & -8.46885 & $0.000^{* * *}$ \\
Panel ADF-statistic & -10.3151 & $0.000^{* * *}$ & -8.4927 & $0.000^{* * *}$ & & & \\
\hline
\end{tabular}

*** Statistical significance at the $1 \%$ level

Table 5 Kao et al. (1999) residual cointegration test results

\begin{tabular}{lcc}
\hline & $\boldsymbol{t}$-Statistic & Prob. \\
\hline ADF & -4.8708 & $0.000^{* * *}$ \\
Residual variance & 0.4482 & \\
HAC variance & 0.2486 & \\
\hline
\end{tabular}

*** Statistical significance at the $1 \%$ level

\subsection{Model specification}

The fundamental objective of our econometric model is to analyse the causal linkage of merger and acquisition with commercial bank productivity in the European Union. Therefore, we estimate a Cobb-Douglas production purpose, where $k 1, k 2$, and $L$ represent the input variables and $Q$ represents the output. The principal purpose of this framing is rather simple, and it is performed to demonstrate the theoretical relationship between merger and acquisition and commercial bank productivity. The output $(Q)$ of commercial European banks $i$ at time $t$ can be expressed as follows:

$$
Q_{\mathrm{it}}=\operatorname{tech} L_{\mathrm{it}}^{\alpha} K_{\mathrm{it}}^{\beta}
$$

where $L$ and $K$ are the different factors of production, tech is a parameter that describes the developmental level of the technology of the commercial European banks, and $\alpha$ and $\beta$ are coefficients that denote the effect of various factors on total production. To estimate the model, it is important to linearize it in logarithmic form. Model (1) appears as follows:

$$
\operatorname{Ln}\left(Q_{\mathrm{it}}\right)=\operatorname{Ln}(\text { tech })+\alpha \operatorname{Ln}\left(L_{\mathrm{it}}\right)+\beta \operatorname{Ln}\left(K_{\mathrm{it}}\right)
$$

A benefit of this method is that the econometric model can include the impact of technological change in the effect of mergers and acquisitions on the productivity of commercial banks in the European Union. Thus, we can observe the effect of mergers and acquisitions on productivity when banks are consolidated by inserting dummy variables (i.e. $A_{0}, A_{1}, A_{2}, A_{3}$ and $A$ ). Therefore, model (2) can be expressed as follows:

$$
\operatorname{Ln}\left(Q_{\mathrm{it}}\right)=\operatorname{Ln}(\text { tech })+\alpha \operatorname{Ln}\left(L_{\mathrm{it}}\right)+\beta \operatorname{Ln}\left(K_{\mathrm{it}}\right)+\sum_{j} \gamma_{j} \text { merger } j_{i, t}
$$

where $i$ denotes the bank $(1 ; 2 ; \ldots ; 157)$, j denotes the number of years post-merger and acquisition $(j=0,1 \ldots, 3$ and more $)$, and $t$ denotes the year $(t=2005 \ldots, 2013) . \alpha, \beta$ are 
the parameters to be estimated and measure the influence of the variables of the model (labour and capital), and $\gamma_{j}$ measures the effect of mergers and acquisitions. To analyse the temporal effect of mergers and acquisitions on bank productivity in our sample, we adopt the following formalization:

$$
\operatorname{Ln}\left(Q_{\mathrm{it}}\right)=\operatorname{Ln}(\operatorname{tech})+\alpha \operatorname{Ln}\left(L_{\mathrm{it}}\right)+\beta \operatorname{Ln}\left(K_{\mathrm{it}}\right)+\sum_{j=0}^{j=3} \gamma_{j} A j_{i t}+\alpha_{i}+u_{i t},
$$

where $i$ denotes the bank $(1,2 \ldots, 157), j$ denotes the number of years post-merger and acquisition $(j=0,1 \ldots, 3$ and more $)$ and $t$ denotes the year $(t=2005 \ldots 2013), \alpha, \beta$ are the parameters to be estimated and measure the influence of the variables of the model (labour and capital), $\gamma_{j}$ measures the effect of mergers and acquisitions, and $A j_{\text {it }}$ is a dummy variable that reflects the time horizon in which the dynamics of mergers and acquisitions are realized. For example, $A_{11(t=2005)}$ indicates that in 2005 banks $(i=1)$ were 1 year post-merger. $\alpha_{i}$ is the bank fixed effect. Table 6 provides the number of sample banks by country and the banks that performed mergers and acquisitions.

\subsection{Granger causality test}

Granger causality is used to analyse the causal links among variables. Engle and Granger (1987) observe that if two variables that share a unit root are integrated, a vector autoregression (VAR) on first differences will be poorly specified. In this research, $\ln Q, \ln K 1$, $\ln K 2$, and $\ln L$ are integrated in order I (1) and therefore have a long-term association. To analyse this association, we adopt an empirical model with an error correction term (ECT) augmented with a lagged period. The Granger causality test is based on the following representation:

$$
\begin{aligned}
\Delta \ln Q_{i t}= & \alpha_{i}+\sum_{j=1}^{q} \beta_{1 i} \Delta \ln K 1_{i t-j}+\sum_{j=1}^{q} \beta_{2 i} \Delta \ln K 2_{i t-j} \\
& +\sum_{j=1}^{q} \beta_{3 i} \Delta \ln L_{i t-j}+\sum_{j=0}^{j=3} \gamma_{j} A j_{i t}+\delta_{1 i} \mathrm{ECT} 1_{i t-1}+\varepsilon_{i t},
\end{aligned}
$$

with:

$$
\mathrm{ECT} 1_{i t}=\ln Q_{i t}-\widehat{\beta_{1 i}} \ln k 1_{i t}-\widehat{\beta_{2 i}} \ln K 2_{i t}-\widehat{\beta_{3 i}} \ln L_{i t}-\gamma_{j} A j_{i t},
$$

where $\Delta$ represents the first difference of the variable and $q$ indicates the lag order automatically specified by the Schwarz information criterion (SIC) and the Akaike information criterion (AIC). The outcome of this lagged vector autoregression (VAR) indicates that all the criteria exhibit a maximum lag equal to the unit (VAR $(q=1)$ ). The ECT is obtained from the long-term cointegration relationship (Eq. 4), $A j_{i t}$ represents the dummy variables of mergers and acquisitions, and $\varepsilon$ is the random error term.

Table 7 presents the results of a short-run Granger causality test (pairwise Granger causality tests). The results suggest bidirectional short-term causality among $\ln k 1$, $\ln k 2, \ln L$, and $\ln Q$, significant at $1 \%$ and $5 \%$, and similar causality between $\ln k 1$ and $\ln L$. Unidirectional short-term causality from liquid assets to fixed assets is significant 
Table 6 Number of acquisitions and number of sample banks by country

\begin{tabular}{lccl}
\hline Country & Number of banks & $\begin{array}{l}\text { Banks that performed mergers } \\
\text { and acquisitions }\end{array}$ & Average size \\
\hline Portugal & 1 & 1 & 3281,652 \\
Czech Republic & 2 & 2 & 57153,872 \\
Cyprus & 2 & 0 & 6150,965 \\
Denmark & 1 & 0 & 1543,140 \\
Ireland & 6 & 1 & 16423,690 \\
Poland & 1 & 0 & 2313,865 \\
Malta & 3 & 0 & 1713,338 \\
Latvia & 4 & 1 & 263,284 \\
Belgium & 5 & 2 & 15656,358 \\
Hungary & 5 & 3 & 2000,940 \\
Germany & 3 & 1 & 1295,544 \\
Finland & 1 & 1 & 176972,937 \\
Estonia & 2 & 0 & 3628,529 \\
Romania & 10 & 2 & 2159,378 \\
Slovakia & 2 & 0 & 1159,598 \\
Sweden & 1 & 1 & 340611,302 \\
Spain & 3 & 1 & 2861,071 \\
Greece & 157 & 3 & 22756,081 \\
Bulgaria & 4 & 1 & 3250,130 \\
France & 8 & 8 & 766,420 \\
UK & 14 & 10 & 18954,012 \\
Luxembourg & 37 & 3542,045 \\
Austria & 32 & 1489,711 \\
Total & 6 & - & \\
\hline
\end{tabular}

"Average size" is average assets in millions of euro for banks in each country for the period 2005-2013

at $1 \%$. Bidirectional short-term causality is found between $\ln k 1$ and $\ln L$. The shortterm causality between $\ln k 2$ and $\ln L$ is unobservable.

With respect to Eq (5), the error correction term (ECT) is negative and statistically significant for all models at $1 \%$ (Table 8 ), which implies a bidirectional relationship between all variables and a long-term unidirectional relationship between mergers and acquisitions $(M \& A)$ and bank productivity.

Table 8 describes the results of short- and long-run Granger two-step causality tests between all selected variables. The total productivity of commercial banks in the European Union exhibits an adjustment process for this productivity of $22 \%$ because the values of the ECT are negative and statistically significant at $1 \%$.

The coefficient of the dummy variable $\left(A_{0}\right)$ is positive and significant at $5 \%$. Thus, mergers and acquisitions (M\&A) had a positive effect on total productivity. Thus, the merged banks experienced efficiency gains in productivity at the moment of acquisition.

However, the effects of the dummy variables $\left(A_{1}, A_{2}, A_{3}, A\right)$ were all non-significant. This outcome implies that at the moment of acquisition the banks were starting to develop new strategies to restructure their new labour and capital stocks and adopting new organizational strategies and human resources management. Therefore, it would be 
Table 7 Panel pairwise granger causality tests

\begin{tabular}{|c|c|c|c|}
\hline Null Hypothesis & Obs & F-Statistic & Prob. \\
\hline InK1 does not Granger Cause InQ & 1099 & 23.6069 & 9. $E-11^{* * *}$ \\
\hline InQ does not Granger Cause InK1 & 4.92614 & $0.0074^{* *}$ & \\
\hline InK2 does not Granger Cause InQ & 1099 & 19.4910 & 5. $E-09^{* * *}$ \\
\hline InQ does not Granger Cause InK2 & 8.62601 & $0.0002^{* * *}$ & \\
\hline InL does not Granger Cause In $Q$ & 1099 & 10.9973 & 2. $E-05^{* * *}$ \\
\hline InQ does not Granger Cause InL & 4.73764 & $0.0089^{* *}$ & \\
\hline InK2 does not Granger Cause InK1 & 1099 & 0.88350 & 0.4136 \\
\hline InK1 does not Granger Cause InK2 & 8.66642 & $0.0002^{* * *}$ & \\
\hline InL does not Granger Cause InK1 & 1099 & 3.59800 & $0.0277^{* *}$ \\
\hline InK1 does not Granger Cause InL & 15.5165 & 2. $E-07^{* * *}$ & \\
\hline In $L$ does not Granger Cause InK2 & 1099 & 1.29441 & 0.2745 \\
\hline InK2 does not Granger Cause InL & 1.96337 & 0.1409 & \\
\hline
\end{tabular}

***,** Significance at the 1 and $5 \%$ levels, respectively

difficult in the short term to attribute an efficiency gain in productivity only to the fact that the banks experienced mergers and acquisitions (M\&A).

Regarding the size effect, which is essentially expressed by the factors of production $(\ln K 1, \ln K 1$, and $\ln L)$, we note that these factors are positive and significant. In fact, mergers enable banks to benefit from an increase in size because this increase means they will have more resources in terms of capital and labour. However, despite this improvement, in the short term, all production factors are unaffected.

Therefore, the scale of bank productivity cannot be revised by changing the quantity of all production factors. These findings are similar to those of Carbó and Molyneux (2009), who examined a Spanish sample over the period 1986-2000 and concluded that approximately one-third of Spanish savings banks benefited from significant cost reductions due to mergers. Our results indicate that productivity improvements are not general but heavily dependent on the identity of the merged banks.

\subsection{Long term with FMOLS and DOLS}

For all selected variables with the same order of integration I (1) for different models, we estimate the long-term coefficients by using the fully modified ordinary least squares (FMOLSs) and dynamic ordinary least squares (DOLSs). For the panel data, FMOLS was developed by Pedroni $(2001,2004)$, while the DOLS approach was developed by Kao and Chiang (2001) and Mark and Sul (2003). These two techniques are used in the event of a unique long-term cointegration vector. The results of long-run estimates using these two techniques are reported in Tables 9 and 10. The coefficients of the long-term elasticities are approximately similar according to the two techniques.

The long-term elasticity of productivity with respect to capital stock is on average 0.196 and higher than the short-term elasticity (0.191). However, the case of the labour stock is different. Here, the long-term productivity elasticity is on average 0.28 and lower than the short-term elasticity (0.35). Thus, we can conclude that in the short- and longterm models, capital and labour well explain the productivity of commercial banks in the European Union, while the gain effect of mergers and acquisitions is unobservable in the 







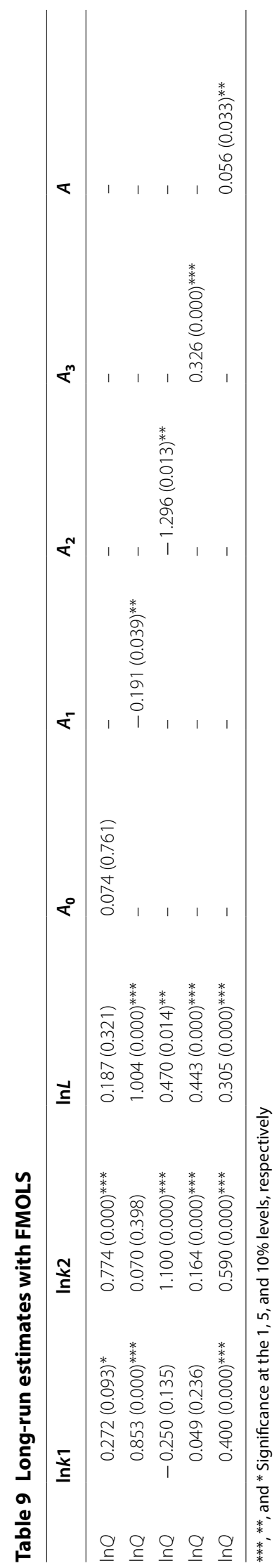




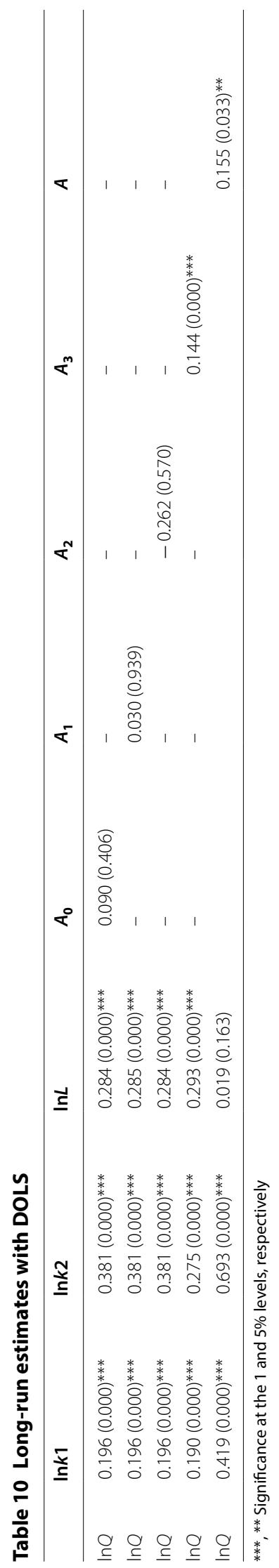


short term. Therefore, short-term effects (i.e. $A_{1}: 1$ year after the merger and acquisition; $A_{2}: 2$ years after the merger and acquisition) are negative and statistically insignificant.

As we progress away from the time of acquisition or merger, the banks make more productivity gains. This outcome is explained by the positive and significant coefficients associated with the dummy variables (i.e. $A_{0}, A_{3}$, and $A$ for FMOLS and $A_{3}$ and A for the DOLS). Consequently, we can state fairly confidently that these mergers and acquisitions do not generate dynamic efficiency (expressed in terms of productivity gains) until the third year post-merger and acquisition. We can also note that as the merged or integrated banks progress from the time of acquisition they become more productive. This statement is supported by the fact that the coefficients associated with capital and labour 3 years post-merger are relatively higher than those associated with previous years.

Based on our results, we can assume that mergers and acquisitions create banks' productivity improvements in the EU. As previously mentioned, one reason for this result could be related to the resolution of the problems that the banking entities face during the long-term integration of the culture of the merged entities and organizational issues. These findings are similar to those of Amel et al. (2004).

Finally, the deregulation process in the banking industry that has occurred in most developed countries, particularly in the European Union, with the subsequent increase in the level of competition, forced banking entities to react to a new competitive scenario. Mergers and acquisitions were a frequent response in many European countries, and good management of the integration process and the consolidating banks clearly contributed to the success of mergers and acquisitions. In fact, problems related to the integration process may be more similar in a sample with a high level of homogeneity (as in this paper) than in heterogeneous samples. Nagano and Ushijima (2018) examined the effect of the deregulation process on an interregional bank branch in Japan over the period 2000-2012. Their empirical findings show that geographical distance increases the probability of interregional branch closure.

Acknowledgements

We are grateful for the helpful comments from the editor and two anonymous referees.

Authors' contributions

All the authors have equally contributed to designing the study, studying concepts or design, dealing with data collection, and calculation so as to write the manuscript. All authors read and approved the final manuscript.

Funding

Not available.

Ethics approval and consent to participate

Not applicable.

Consent for publication

Not applicable.

Competing interests

The authors declare that they have no competing interests.

Author details

${ }^{1}$ Department of Management, College of Business Administration in Yanbu, Taibah University, Madina, Kingdom of Saudi Arabia. ${ }^{2}$ University of Economics and Management of Sfax, (URED), Street of Airport km 4.5, LP 1088, 3018 Sfax, Tunisia.

\section{Appendix}

See Table 11. 
Table 11 Data from Bankscope databases

\begin{tabular}{|c|c|c|c|}
\hline Country & $\begin{array}{l}\text { Banks } \\
\text { that performed } \\
\text { acquisitions }\end{array}$ & Time of M\&A & Acquired or merged banks \\
\hline Portugal & $\begin{array}{l}\text { Deutsche Bank (Portu- } \\
\text { gal) SA }\end{array}$ & 2011 & $\begin{array}{l}\text { On } 1 \text { August 2011, Deutsche Bank (Portugal) } \\
\text { SA was absorbed by Deutsche Bank Europe } \\
\text { GmbH. }\end{array}$ \\
\hline \multirow[t]{2}{*}{ Czech Republic } & $\begin{array}{l}\text { UniCredit Bank Slova- } \\
\text { kia AS }\end{array}$ & 2013 & $\begin{array}{l}\text { On } 1 \text { December 2013, UniCredit Bank Slo- } \\
\text { vakia AS was absorbed by UniCredit Bank } \\
\text { Czech Republic and Slovakia AS }\end{array}$ \\
\hline & $\begin{array}{l}\text { UniCredit Bank Czech } \\
\text { Republic and Slova- } \\
\text { kia AS }\end{array}$ & 1999/2001/2007/2013 & $\begin{array}{l}\text { On } 1 \text { January 1999, Vereinsbank (CZ) AS } \\
\text { absorbed Hypobank CZ AS } \\
\text { On } 1 \text { October 2001, Vereinsbank (CZ) AS } \\
\text { absorbed Bank Austria Creditanstalt Czech } \\
\text { Republic } \\
\text { On } 5 \text { November 2007, HVB Bank Czech } \\
\text { Republic AS absorbed Zivnostenska banka, } \\
\text { AS } \\
\text { On } 1 \text { December 2013, UniCredit Bank Czech } \\
\text { Republic AS absorbed UniCredit Bank } \\
\text { Slovakia AS }\end{array}$ \\
\hline Ireland & $\begin{array}{l}\text { Ulster Bank Ireland } \\
\text { Limited }\end{array}$ & 2010 & $\begin{array}{l}\text { In 2010, Ulster Bank Ireland Limited absorbed } \\
\text { First Active PLC }\end{array}$ \\
\hline Latvia & $\begin{array}{l}\text { Jsc Latvian Develop- } \\
\text { ment Financial } \\
\text { Institution Altum }\end{array}$ & 1997 & $\begin{array}{l}\text { In 1997, Jsc Latvian Development Financial } \\
\text { Institution Altum absorbed Latvian Agricul- } \\
\text { tural Finance Company }\end{array}$ \\
\hline \multirow[t]{2}{*}{ Belguim } & Record Bank SA/NV & 1995/2005/2006 & $\begin{array}{l}\text { In 1995, absorbed Sofibanque SA } \\
\text { In May 2005, absorbed Mercator Bank nv } \\
\text { In June 2006, absorbed Eural SA/NV }\end{array}$ \\
\hline & $\begin{array}{l}\text { ING Belgium SA/ } \\
\text { NV-ING }\end{array}$ & 1975/2003/2006/2006 & $\begin{array}{l}\text { On } 30 \text { June 1975, as a result of the merger } \\
\text { between Banque Lambert and Banque de } \\
\text { Bruxelles. } \\
\text { On } 5 \text { May 2003, absorbed Caisse Privée } \\
\text { Banque. } \\
\text { In June 2006, absorbed ING Bank (France) SA. } \\
\text { In September 2006, absorbed ING Securities } \\
\text { Bank (France) SA. }\end{array}$ \\
\hline \multirow[t]{3}{*}{ Hungary } & $\begin{array}{l}\text { Banco Popolare Hun- } \\
\text { gary Bank Zrt }\end{array}$ & 2013 & $\begin{array}{l}\text { In 2013, Banco Popolare Hungary Bank } \\
\text { Zrt was absorbed by MagNet Magyar } \\
\text { Koezoessegi Bank Zrt }\end{array}$ \\
\hline & $\begin{array}{l}\text { Calyon Bank Magya- } \\
\text { rorszag Zrt-Calyon } \\
\text { Bank Hungary }\end{array}$ & 2007 & $\begin{array}{l}\text { In October 2007, absorbed by Credit Agricole } \\
\text { Corporate and Investment Bank }\end{array}$ \\
\hline & $\begin{array}{l}\text { Erste Bank Hungary } \\
\quad \text { Nyrt }\end{array}$ & $1996 / 2004$ & $\begin{array}{l}\text { In January 1996, absorbed Agrobank RT } \\
\text { On } 31 \text { August } 31 \text { 2004, absorbed Postbank } \\
\text { and Savings Bank Corp }\end{array}$ \\
\hline Germany & $\begin{array}{l}\text { Mizuho Corporate } \\
\text { Bank (Germany) AG }\end{array}$ & 2009 & On 30 November 2009, in liquidations \\
\hline Finland & $\begin{array}{l}\text { Nordea Bank Finland } \\
\text { Plc }\end{array}$ & 2000/2001/2002 & $\begin{array}{l}\text { In December 2000, absorbed Merita Plc } \\
\text { On } 30 \text { September 2001, absorbed Merita } \\
\text { Bank Plc } \\
\text { Demerged on January } 2002 \text { into five new } \\
\text { companies }\end{array}$ \\
\hline \multirow[t]{2}{*}{ Romania } & $\begin{array}{l}\text { Intesa Sanpaolo Bank } \\
\text { Romania SA }\end{array}$ & 2012 & Absorbed Banca CR Firenze Romania SA \\
\hline & $\begin{array}{l}\text { Banca Comerciala } \\
\text { Romana SA-Roma- } \\
\text { nian Commercial } \\
\text { Bank SA }\end{array}$ & 1999 & $\begin{array}{l}\text { In October 1999, absorbed Banca Romana de } \\
\text { Comert Exterior SA-Bancorex }\end{array}$ \\
\hline
\end{tabular}


Table 11 (continued)

\begin{tabular}{|c|c|c|c|}
\hline Country & $\begin{array}{l}\text { Banks } \\
\text { that performed } \\
\text { acquisitions }\end{array}$ & Time of M\&A & Acquired or merged banks \\
\hline Sweeden & $\begin{array}{l}\text { Nordea Bank Sweden } \\
\text { AB (publ) }\end{array}$ & $1994 / 2002 / 2004$ & $\begin{array}{l}\text { On } 1 \text { October 1994, absorbed Gota Bank } \\
\text { In December 2002, absorbed Postgirot Bank } \\
\text { On } 1 \text { March 2004, Nordea Bank Sweden AB } \\
\text { (publ) was absorbed by Nordea Bank AB } \\
\text { (publ) }\end{array}$ \\
\hline Spain & $\begin{array}{l}\text { Banco de Credito } \\
\text { Local d'España }\end{array}$ & 1999/2009 & $\begin{array}{l}\text { In March 1999, absorbed Dexia Banco Local } \\
\text { On } 17 \text { June 2009, Banco de Crédito Local } \\
\text { de España was absorbed by Banco Bilbao } \\
\text { Vizcaya Argentaria SA }\end{array}$ \\
\hline \multirow[t]{3}{*}{ Greece } & $\begin{array}{l}\text { Emporiki Bank of } \\
\text { Greece SA }\end{array}$ & 2013 & $\begin{array}{l}\text { On } 28 \text { June 2013, Emporiki Bank of Greece SA } \\
\text { was absorbed by Alpha Bank AE. }\end{array}$ \\
\hline & $\begin{array}{l}\text { Agricultural Bank of } \\
\text { Greece }\end{array}$ & 2012 & $\begin{array}{c}\text { On } 30 \text { July 2012, Agricultural Bank of Greece } \\
\text { was absorbed by Piraeus Bank SA }\end{array}$ \\
\hline & $\begin{array}{l}\text { National Bank of } \\
\text { Greece SA }\end{array}$ & $1998 / 2002$ & $\begin{array}{l}\text { In August 1998, National Bank of Greece } \\
\text { SA absorbed National Mortgage Bank of } \\
\text { Greece SA } \\
\text { In December 2002, absorbed National Invest- } \\
\text { ment Bank for Industrial Development } \\
\text { SA-ETEBA }\end{array}$ \\
\hline \multirow[t]{8}{*}{ France } & $\begin{array}{l}\text { KBL Richelieu Banque } \\
\text { Privée }\end{array}$ & 2008 & $\begin{array}{l}\text { On } 1 \text { November 2008, the activity of KBL } \\
\text { Richelieu Banque Privée ceased }\end{array}$ \\
\hline & Banque Saradar France & 2005 & $\begin{array}{l}\text { In April 2005, Banque Saradar France was } \\
\text { absorbed by Banque Audi Saradar France } \\
\text { SA }\end{array}$ \\
\hline & Aareal Bank France SA & 2010 & $\begin{array}{l}\text { In April 2010, Aareal Bank France SA was } \\
\text { absorbed by Aareal Bank AG }\end{array}$ \\
\hline & $\begin{array}{l}\text { Banque Audi Saradar } \\
\text { France SA }\end{array}$ & 2005 & $\begin{array}{l}\text { In April 2005, Banque Audi France SA } \\
\text { absorbed Banque Saradar France }\end{array}$ \\
\hline & Credit Suisse (France) & 1997 & $\begin{array}{l}\text { On } 31 \text { December 1997, Credit Suisse (France) } \\
\text { SA absorbed Banque Hottinguer }\end{array}$ \\
\hline & $\begin{array}{l}\text { Banca Intesa (France) } \\
\text { SA }\end{array}$ & $2003 / 2008$ & $\begin{array}{l}\text { On } 1 \text { September 2003, Banca Commerciale } \\
\text { Italiana (France) absorbed CPR } \\
\text { In September 2008, absorbed by Intesa } \\
\text { Sanpaolo }\end{array}$ \\
\hline & $\begin{array}{l}\text { UBS Wealth Manage- } \\
\text { ment (France) SA (in } \\
2003 \text { took the name } \\
\text { UBS (France) SA) }\end{array}$ & 2003 & $\begin{array}{l}\text { On } 1 \text { November 2003, absorbed UBS (France) } \\
\text { SA }\end{array}$ \\
\hline & HSBC France & $2002 / 2008 / 2010$ & $\begin{array}{l}\text { In April 2002, absorbed HSBC CCF Investment } \\
\text { Bank (France) } \\
\text { On } 31 \text { July 2008, absorbed HSBC Hervet, } \\
\text { HSBC de Baecque Beau SA, HSBC UBP and } \\
\text { HSBC Picardie } \\
\text { In June 2010, absorbed HSBC Financial Prod- } \\
\text { ucts (France) SNC }\end{array}$ \\
\hline \multirow[t]{4}{*}{ UK } & $\begin{array}{l}\text { Citibank International } \\
\text { Plc }\end{array}$ & 2000 & $\begin{array}{l}\text { On } 28 \text { April 2000, Citibank International Plc } \\
\text { absorbed Citibank Portugal S.A. }\end{array}$ \\
\hline & Clydesdale Bank Plc & 2004 & $\begin{array}{l}\text { In December 2004, Clydesdale Bank PIc } \\
\text { absorbed Yorkshire Bank Plc }\end{array}$ \\
\hline & $\begin{array}{l}\text { Co-operative Bank Plc } \\
\text { (The) }\end{array}$ & 2009 & $\begin{array}{l}\text { On } 1 \text { August 2009, Co-operative Bank Plc } \\
\text { absorbed Britannia Building Society }\end{array}$ \\
\hline & $\begin{array}{l}\text { Alliance and Leicester } \\
\text { Plc }\end{array}$ & $2001 / 2011$ & $\begin{array}{l}\text { In December 2001, Alliance and Leicester } \\
\text { PLC absorbed Alliance and Leicester Group } \\
\text { Treasury Plc } \\
\text { In 2011, transferred to Santander UK Plc. }\end{array}$ \\
\hline
\end{tabular}


Table 11 (continued)

\begin{tabular}{|c|c|c|c|}
\hline Country & $\begin{array}{l}\text { Banks } \\
\text { that performed } \\
\text { acquisitions }\end{array}$ & Time of M\&A & Acquired or merged banks \\
\hline & Santander UK PIC & 1944/1996 & $\begin{array}{l}\text { In 1944, as The Abbey National Building } \\
\text { through the merger of Abbey Road Build- } \\
\text { ing Society and The National Building } \\
\text { Society } \\
\text { In 1996, absorbed National and Provincial } \\
\text { Building Society }\end{array}$ \\
\hline & $\begin{array}{l}\text { National Westminster } \\
\text { Bank Plc—NatWest }\end{array}$ & 1968/1970 & $\begin{array}{l}\text { In 1968, as the result of the merger between } \\
\text { The Boards National Provincial and West- } \\
\text { minster Bank } \\
\text { On } 1 \text { January 1970, merging of the District } \\
\text { Bank, National Provincial Bank, and West- } \\
\text { minster Bank into National Westminster } \\
\text { Bank }\end{array}$ \\
\hline & $\begin{array}{l}\text { Standard Chartered } \\
\text { Bank }\end{array}$ & 2008 & $\begin{array}{l}\text { In September 2008, Standard Chartered Bank } \\
\text { absorbed American Express Bank Ltd. }\end{array}$ \\
\hline & Bank of Scotland Plc & $2001 / 2007 / 2010$ & $\begin{array}{l}\text { In November 2001, Bank of Scotland } \\
\text { absorbed Bank of Wales Plc } \\
\text { On } 17 \text { September 2007, Bank of Scotland } \\
\text { absorbed Halifax PIc, HBOS Treasury Ser- } \\
\text { vices Plc and Capital Bank Plc and changed } \\
\text { its name to Bank of Scotland Plc } \\
\text { On } 31 \text { December 2010, Bank of Scotland PIc } \\
\text { absorbed Bank of Scotland (Ireland) Limited }\end{array}$ \\
\hline & $\begin{array}{l}\text { Royal Bank of Scotland } \\
\text { Plc (The) }\end{array}$ & 1969 & $\begin{array}{l}\text { In April 1969, merged with National Com- } \\
\text { mercial Bank of Scotland }\end{array}$ \\
\hline & Abbey National Plc & 1996 & $\begin{array}{l}\text { In 1996, absorbed National and Provincial } \\
\text { Building Society }\end{array}$ \\
\hline \multirow[t]{8}{*}{ Luxembourg } & $\begin{array}{l}\text { Hauck and Aufhäuser } \\
\text { Banquiers Luxem- } \\
\text { bourg SA }\end{array}$ & 2013 & $\begin{array}{l}\text { In October 2013, the activity of Hauck and } \\
\text { Aufhäuser Banquiers Luxembourg SA } \\
\text { ceased }\end{array}$ \\
\hline & $\begin{array}{l}\text { VP Bank (Luxembourg) } \\
\text { SA }\end{array}$ & 2001 & $\begin{array}{l}\text { On } 31 \text { December 2001, absorbed Banque } \\
\text { Baumann and Cie SA. }\end{array}$ \\
\hline & $\begin{array}{l}\text { Banco Itau Europa } \\
\text { Luxembourg }\end{array}$ & 2009 & $\begin{array}{l}\text { On } 25 \text { August 2009, Banco Itau Europa Lux- } \\
\text { embourg absorbed Unibanco_Uniao de } \\
\text { Bancos Brasileiros (Luxembourg) SA }\end{array}$ \\
\hline & $\begin{array}{l}\text { Kaupthing Bank Lux- } \\
\text { embourg SA }\end{array}$ & 2009 & $\begin{array}{l}\text { On } 10 \text { July 2009, Kaupthing Bank Luxem- } \\
\text { bourg SA was dissolved without liquidation }\end{array}$ \\
\hline & $\begin{array}{l}\text { Banque Degroof } \\
\text { Luxembourg SA }\end{array}$ & 2006 & $\begin{array}{l}\text { In January 2006, Banque Degroof Luxem- } \\
\text { bourg SA absorbed Banque Nagelmackers } \\
\text { (Luxembourg) SA }\end{array}$ \\
\hline & $\begin{array}{l}\text { Credit Agricole Luxem- } \\
\text { bourg SA }\end{array}$ & 1997/1999/2005/2008 & $\begin{array}{l}\text { On } 1 \text { December } 1997 \text { (effective as of } 1 \text { July } \\
\text { 1997) absorbed Banque Indosuez Luxem- } \\
\text { bourg SA and its name changed to Crédit } \\
\text { Agricole Indosuez Luxembourg SA } \\
\text { On } 30 \text { April 1999, absorbed Banque de Ges- } \\
\text { tion Privée de Luxembourg } \\
\text { On } 1 \text { July 2005, absorbed Crédit Lyonnais } \\
\text { Luxembourg SA and changed its name to } \\
\text { Crédit Agricole Luxembourg SA } \\
\text { On } 26 \text { April 2008, absorbed Crédit Agricole } \\
\text { Luxembourg Bank }\end{array}$ \\
\hline & $\begin{array}{l}\text { Credit Suisse (Luxem- } \\
\text { bourg) SA }\end{array}$ & 2002 & $\begin{array}{l}\text { On } 1 \text { January 2002, Crédit Suisse (Luxem- } \\
\text { bourg) SA absorbed Banque Leu (Luxem- } \\
\text { bourg) SA }\end{array}$ \\
\hline & $\begin{array}{l}\text { JP Morgan Bank Lux- } \\
\text { embourg SA }\end{array}$ & 1998 & $\begin{array}{l}\text { On } 1 \text { December 1998, Chase Manhattan } \\
\text { Bank Luxembourg SA absorbed Morgan } \\
\text { Stanley Bank Luxembourg In November } \\
\text { 2001, changed its name to JP Morgan Bank } \\
\text { Luxembourg SA }\end{array}$ \\
\hline
\end{tabular}


Table 11 (continued)

\begin{tabular}{|c|c|c|c|}
\hline Country & $\begin{array}{l}\text { Banks } \\
\text { that performed } \\
\text { acquisitions }\end{array}$ & Time of $M \& A$ & Acquired or merged banks \\
\hline & $\begin{array}{l}\text { Dresdner Bank Luxem- } \\
\text { bourg SA }\end{array}$ & 2010 & $\begin{array}{l}\text { In April 2010, Dresdner Bank Luxembourg SA } \\
\text { was absorbed by Commerzbank Interna- } \\
\text { tional SA }\end{array}$ \\
\hline & $\begin{array}{l}\text { Landsbanki Luxem- } \\
\text { bourg SA }\end{array}$ & 2008 & $\begin{array}{l}\text { In December 2008, the District Court of Lux- } \\
\text { embourg has ordered the dissolution and } \\
\text { winding-up of Landsbanki Luxembourg SA }\end{array}$ \\
\hline & $\begin{array}{l}\text { Deutsche Bank Lux- } \\
\text { embourg SA }\end{array}$ & 1999 & $\begin{array}{l}\text { In December 1999, absorbed Bankers Trust } \\
\text { Luxembourg }\end{array}$ \\
\hline & UBS (Luxembourg) SA & 1996/1998/2002 & $\begin{array}{l}\text { as Union de Banques Suisses (Luxembourg) } \\
\text { SA } \\
\text { In 1996, absorbed Société de Banque Suisse } \\
\text { (Luxembourg) SA } \\
\text { On } 29 \text { May 1998, merged with Swiss Bank } \\
\text { Corporation (Luxembourg) Ltd. } \\
\text { In August 2002, absorbed Banque Ferrier } \\
\text { Lullin (Luxembourg) SA }\end{array}$ \\
\hline & $\begin{array}{l}\text { DekaBank Deutsche } \\
\text { Girozentrale Luxem- } \\
\text { bourg SA }\end{array}$ & 2002 & $\begin{array}{l}\text { On } 1 \text { January 2002, Deutsche Girozentrale } \\
\text { International SA absorbed DekaBank } \\
\text { (Luxemburg) SA }\end{array}$ \\
\hline & ING Luxembourg & 2003 & $\begin{array}{l}\text { In May 2003, absorbed ING Bank (Luxem- } \\
\text { bourg) SA }\end{array}$ \\
\hline & $\begin{array}{l}\text { KBL European Private } \\
\text { Bankers SA }\end{array}$ & 2005 & $\begin{array}{l}\text { On } 1 \text { January 2005, Krediet Bank SA Lux- } \\
\text { embourgeoise KBL absorbed Banque Conti- } \\
\text { nentale du Luxembourg SA }\end{array}$ \\
\hline & $\begin{array}{l}\text { UniCredit Luxembourg } \\
\text { SA }\end{array}$ & 1998 & $\begin{array}{l}\text { On } 1 \text { November } 1998 \text { through the merger } \\
\text { between Vereinsbank International SA and } \\
\text { Hypobank International SA }\end{array}$ \\
\hline & $\begin{array}{l}\text { Banque Internationale } \\
\text { Luxembourg SA }\end{array}$ & $2001 / 2002$ & $\begin{array}{l}\text { In November 2001, absorbed Dexia Direct } \\
\text { Bank SA. } \\
\text { In November 2002, absorbed Dexia Nordic } \\
\text { Private Bank SA }\end{array}$ \\
\hline & $\begin{array}{l}\text { BNP Paribas Luxem- } \\
\text { bourg }\end{array}$ & 2001/2006/2007/2010 & $\begin{array}{l}\text { In July } 2001 \text { through the merger of Banque } \\
\text { Nationale de Paris (Luxembourg) SA BNP } \\
\text { and Paribas Luxembourg } \\
\text { In April 2006, BNP Paribas Luxembourg } \\
\text { absorbed United European Bank (Luxem- } \\
\text { bourg) SA } \\
\text { On } 31 \text { March 2007, absorbed Banca Nazion- } \\
\text { ale del Lavoro International SA } \\
\text { On } 5 \text { October 2010, BNP Paribas Luxembourg } \\
\text { was absorbed by BGL BNP Paribas }\end{array}$ \\
\hline \multirow[t]{4}{*}{ Austria } & Arab Bank (Austria) AG & 2006 & $\begin{array}{l}\text { In 2006, the business of Arab Bank (Austria) } \\
\text { AG was transferred to Europe Arab Bank Plc. }\end{array}$ \\
\hline & $\begin{array}{l}\text { Valartis Bank (Austria) } \\
\text { AG }\end{array}$ & 1998 & $\begin{array}{l}\text { In October 1998, Anglo Irish Bank (Austria) } \\
\text { A.G absorbed Crédit Lyonnais Bank (Austria) } \\
\text { AG }\end{array}$ \\
\hline & $\begin{array}{l}\text { Kommunalkredit } \\
\text { Austria AG }\end{array}$ & 2009 & $\begin{array}{l}\text { On } 28 \text { November 2009, Kommunalkredit } \\
\text { Depotbank AG acquired the banking busi- } \\
\text { ness of KA Finanz AG and changed its name } \\
\text { to Kommunalkredit Austria AG }\end{array}$ \\
\hline & $\begin{array}{l}\text { UniCredit Bank Austria } \\
\text { AG-Bank Austria }\end{array}$ & 1997/2000/2002 & $\begin{array}{l}\text { On } 31 \text { May 1997, absorbed Westdeutsche } \\
\text { Landesbank (Austria) AG } \\
\text { In November 2000, absorbed Sparkasse } \\
\text { Stockerau AG } \\
\text { On } 12 \text { August 2002, absorbed Creditanstalt } \\
\text { AG }\end{array}$ \\
\hline Bulgaria & $\begin{array}{l}\text { Eurobank Bulgaria AD- } \\
\text { Postbank }\end{array}$ & 2007 & $\begin{array}{l}\text { On } 1 \text { November 2007, Bulgarian Post Bank } \\
\text { JSC absorbed DZI Bank AD }\end{array}$ \\
\hline
\end{tabular}


Received: 27 October 2019 Revised: 27 October 2019 Accepted: 3 December 2019

Published online: 16 December 2019

\section{References}

Alarco G (2018) Mergers and acquisitions in Latin America 1990-2014: factorial distribution and contractionary impacts. Metroeconomica 69(3):681-706

Allen L, Rai A (1996) Operational efficiency in banking: an international comparison. J Bank Finance 20(4):655-672 Altunbas Y, Molyneux P (1996) Economies of scale and scope in European banking. Appl Financ Econ 6(4):367-375

Amel D, Barnes C, Panetta F, Salleo C (2004) Consolidation and efficiency in the financial sector: a review of the international evidence. J Bank Finance 28(10):2493-2519

Amewu G, Alagidede P (2018) Do mergers and acquisitions announcements create value for acquirer shareholders in Africa. Int J Financ Econ 23(4):606-627

Ayadi R, Boussemart JP, Leleu H, Saidane D (2013) Mergers and Acquisitions in European banking higher productivity or better synergy among business lines? J Prod Anal 39(2):165-175

Barth JR, Caprio G, Levine R (2004) Bank regulation and supervision: what works best? J Financ Intermed 13(2):205-248

Berger AN, Mester $L J(1997)$ Inside the black box: what explains differences in the efficiencies of financial institutions? J Bank Finance 21(7):895-947

Bonin J, Wachtel P (2003) Financial sector development in transition economies: lessons from the first decade. Financ Mark Inst Instr 12(1):1-66

Brissimis SN, Delis MD, Papanikolaou NI (2008) Exploring the nexus between banking sector reform and performance: evidence from newly acceded EU countries. J Bank Finance 32(12):2674-2683

Carbó S, Humphrey D, Maudos J, Molyneux P (2009) Cross-country comparisons of competition and pricing power in European banking. J Int Money Financ 28(1):115-134

Cavallo L, Rossi SP (2001) Scale and scope economies in the European banking systems. J Multinatl Financ Manag 11(4):515-531

Conyon MJ, Girma S, Thompson S, Wright PW (2002) The productivity and wage effects of foreign acquisition in the United Kingdom. J Indus Econ 50(1):85-102

Du K, Sim N (2016) Mergers, acquisitions, and bank efficiency: cross-country evidence from emerging markets. Res Int Bus Financ 36:499-510

Engle RF, Granger CW (1987) Co-integration and error correction: representation, estimation, and testing. Econometrica 55:251-276

Hassen T, Fakhri I, Bilel A, Wassim T, Faouzi H (2016) Dynamic effects of mergers and acquisitions on the performance of Commercial European Banks. J Knowl Econ 9:1-17

Haynes M, Thompson S (1999) The productivity effects of bank mergers: evidence from the UK building societies. J Bank Finance 23(5):825-846

Kao C, Chiang MH (2001) On the estimation and inference of a cointegrated regression in panel data. Nonstationary panels, panel cointegration, and dynamic panels. Emerald Group Publishing Limited, Bingley, pp 179-222

Kao C, Chiang MH, Chen B (1999) International R\&D spillovers: an application of estimation and inference in panel cointegration. Oxford Bull Econ Stat 61(S1):691-709

Klimek A (2014) Results of cross-border mergers and acquisitions by multinational corporations from emerging countries: the case of Poland. East Eur Econ 52(4):92-104

Levin A, Lin CF, Chu CSJ (2002) Unit root tests in panel data: asymptotic and finite-sample properties. J Econ 108(1):1-24

Lichtenberg FR (1992) Industrial de-diversification and its consequences for productivity. J Econ Behav Organ 18(3):427-438

Mark NC, Sul D (2003) Cointegration vector estimation by panel DOLS and long run money demand. Oxford Bull Econ Stat 65(5):655-680

Montgomery $\mathrm{H}$, Takahashi Y (2018) Are bank mergers good news for shareholders? The effect of bank mergers on shareholder value in Japan. International Review of Finance, Berlin

Nagano M, Ushijima T (2018) What drives interregional bank branch closure? The case of Japan's regional banks in the post deregulation period. International Review of Finance, Berlin

Nurboja B, Košak M (2017) Banking efficiency in South East Europe: evidence for financial crises and the gap between new EU members and candidate countries. Econ Syst 41(2017):122-138

Oberhofer H, Pfaffermayr M (2013) Firm growth in multinational corporate groups. Empir Econ 44(3):1435-1453

Pedroni P (1999) Critical values for cointegration tests in heterogeneous panels with multiple regressors. Oxf Bull Econ Stat 61(S1):653-670

Pedroni P (2001) Fully modified OLS for heterogeneous cointegrated panels. Nonstationary panels, panel cointegration, and dynamic panels. Emerald Group Publishing Limited, Bingley, pp 93-130

Pedroni P (2004) Panel cointegration: asymptotic and finite sample properties of pooled time series tests with an application to the PPP hypothesis. Economet Theory 20(03):597-625

Pozzolo AF (2009) Bank cross-border mergers and acquisitions: causes, consequences, and recent trends. The changing geography of banking and finance. Springer, Berlin, pp 155-183

Rezitis AN (2008) Efficiency and productivity effects of bank mergers: evidence from the Greek banking industry. Econ Model 25(2):236-254

Sealey CW Jr, Lindley JT (1977) Inputs, outputs, and a theory of production and cost at depository financial institutions. J Financ 32(4):1251-1266

Shams S, Gunasekarage A (2019) Competition in the acquisition market and acquirers'long-run performance. International Finance, Cappadocia 
Vander Vennet R (1994) Concentration, efficiency, and entry barriers as determinants of EC bank profitability. J Int Financ Mark Instit Money 4:3-4

Vander Vennet R (1996) The effect of mergers and acquisitions on the efficiency and profitability of EC credit institutions. J Bank Financ 20(9):1531-1558

\section{Publisher's Note}

Springer Nature remains neutral with regard to jurisdictional claims in published maps and institutional affiliations.

Submit your manuscript to a SpringerOpen ${ }^{\circ}$ journal and benefit from:

Convenient online submission

- Rigorous peer review

- Open access: articles freely available online

- High visibility within the field

Retaining the copyright to your article

Submit your next manuscript at $\boldsymbol{\nabla}$ springeropen.com 